\title{
Ovarian follicular development during early pregnancy in cattle
}

\author{
L. A. Guilbault*, J. J. Dufour $\ddagger$, W. W. Thatcher $\dagger$, M. Drost $\dagger$ and \\ G. K. Haibel $\uparrow$ \\ * Agriculture Canada Research Station, Lennoxville, Quebec, Canada JIM IZ3, and $\dagger$ Department of \\ Dairy Science, IFAS University of Florida, Gainesville, FL 32611, U.S.A.
}

\begin{abstract}
Summary. On the day of oestrus (Day 0), 23 cows were assigned randomly to 4 groups in a $2 \times 2$ factorial experiment. Main effects were cow status [pregnant $(P)$ versus non-pregnant (NP; not mated)] and day (Day 17 versus Day 34) when cows were slaughtered and ovaries collected; i.e. Groups NP-17 $(\mathrm{N}=6), \mathrm{NP}-34(\mathrm{~N}=5), \mathrm{P}-17$ $(\mathrm{N}=6)$ and $\mathrm{P}-34(\mathrm{~N}=6)$. To mimic $\mathrm{CL}$ maintenance associated with presence of a conceptus in Group P-34, cows assigned to Group NP-34 were hysterectomized between Days 4 and 6 after oestrus. Pregnancy in Groups P-17 and P-34 (recovery of conceptus) and CL maintenance between day of surgery and Day 34 in Group NP-34 were confirmed. In Group NP-17, all cows except one were slaughtered before luteolysis. CL-bearing ovaries were serially sectioned $(10 \mu \mathrm{m})$ and follicles $(>0.15 \mathrm{~mm})$ were counted and measured using routine histological techniques. For each size class of follicles, the percentages of follicles were similar $(P>0.1)$ on Days 17 and 34. The percentage of non-atretic follicles $(<4$ pycnotic bodies) was lower $(P<0.002)$ in pregnant than non-pregnant groups in the smallest class of antral follicles $(0 \cdot 16-0.28 \mathrm{~mm})$ but was higher $(P<0.03)$ in larger classes $(0.68-3.67 \mathrm{~mm})$ for pregnant groups. Percentages of atretic follicles were 3.7 and $4.9(P>0.1)$ for follicles of $0.16-0.67 \mathrm{~mm}, 91 \cdot 1$ and 78.9 for follicles of $0.68-3.67 \mathrm{~mm}(P<0.04)$ and 5.1 and $16 \cdot 1(P<0.05)$ for follicles of $3.67-78.56 \mathrm{~mm}$ in pregnant and non-pregnant groups respectively. The percentage of atretic follicles classified as late atretic was higher in pregnant than in non-pregnant groups for follicles of $0.68-1.57 \mathrm{~mm}(P<0.06)$ and $3.68-8.56 \mathrm{~mm}(P<0.05)$. The results suggest that, as early as Day 17 , the presence of a conceptus favours a more rapid turnover of follicles from class $1(0 \cdot 16-0.28 \mathrm{~mm})$ to classes 3 and 4 $(0.68-3.67 \mathrm{~mm})$ but limits further growth by increasing atresia.
\end{abstract}

\section{Introduction}

The uterus of the cow controls the life-span of the corpus luteum (CL; Wiltbank \& Casida, 1956; Malven \& Hansel, 1964; Ginther, 1981), most probably via its secretion of prostaglandin (PG) F- $2 \alpha$ (Nancarrow et al., 1973; Shemesh \& Hansel, 1975; Thatcher et al., 1984, 1985). However, involvement of ovarian follicles in control of onset of luteolysis also is likely. Indeed, destruction of large ovarian follicles by X-irradiation (Villa-Godoy et al., 1985; Fogwell, Cowley, Wortman, Ames \& Ireland, 1985) or electrocauterization (Chupin \& Saumande, 1981) lengthens the life-span of the CL whereas injections of oestrogens (which originate from large antral follicles) are luteolytic in cattle (Wiltbank, Ingalls \& Rowden, 1961; Brunner, Donaldson \& Hansel, 1969; Eley, Thatcher \& Bazer, 1979; Hixon et al., 1983). Moreover, inhibition of follicular growth by administration of bovine follicular fluid delays the onset of oestrus (Miller, Critser, Rowe \& Ginther, 1979), suggesting that ovarian follicles also are involved in control of onset of oestrus in cattle.

† Present address: Départment de Zootechnie, Université Laval, Ste-Foy, Québec, Canada G1K 7P4. 
The presence of a conceptus on Day 17 after mating leads to maintenance of CL function (Northey \& French, 1980), presumably by dampening endometrial secretion of PGF-2 $\alpha$ (Thatcher et al., 1985). This antiluteolytic effect of the conceptus may be exerted directly on endometrial cells. However, follicular growth is reduced during mid-pregnancy in cattle (Rexroad \& Casida, 1975). The conceptus of the cow may therefore suppress indirectly the luteolytic process via its effect on ovarian follicular development. The objective of this experiment was to determine the influence of a gravid uterus and/or conceptus on the population of ovarian antral follicles during early pregnancy in cattle.

\section{Materials and Methods}

Animals and experimental design. On the day of oestrus (Day 0), 23 Angus cows which had displayed at least one oestrous cycle were assigned randomly to one of four groups in a $2 \times 2$ factorial experiment. The main effects were cow status [pregnant (P) versus non-pregnant (NP)] and day when cows were slaughtered and ovaries collected (Day 17 versus Day 34). Cows in Groups P-17 $(\mathrm{N}=6)$ and P-34 $(\mathrm{N}=6)$ were inseminated by natural service whereas those in Groups NP-17 $(\mathrm{N}=6)$ and NP-34 $(\mathrm{N}=5)$ were not inseminated.

Cows in Group NP-34 were hysterectomized between Days 4 and 6 after oestrus. The objective of this surgery was to induce CL maintenance in this group of cows and thus mimic CL maintenance associated with the presence of a conceptus in Group P-34. General anaesthesia was induced by rapid infusion of $3-5 \mathrm{~g}$ sodium thiamylal (Bio-Tal, Bio-Ceutic Labs., St-Joseph MO, U.S.A.) dissolved in sterile physiological saline and was maintained by constant inhalation of a mixture of oxygen and fluothane (Vescor, Orlando, FL, U.S.A.). Reproductive organs were exposed through a midventral laparotomy and the CL-bearing ovary was identified. All blood supply to the uterus was occluded by multiple sutures with sterile umbilical tape (Look Inc., Boston, MA, U.S.A.) along the broad ligament proximal to the body and the horns of the uterus. The non-CL- and CL-bearing ovaries and their respective blood supply were left intact. Amputation of the uterus was done so that no more than $1.0 \mathrm{~cm}$ of cervical tissue was left in the animal. For the first 3 days after surgery, cows were given daily i.m. injections of ampicillin (Polyflex, Bristol Veterinary Products, Syracuse, NY, U.S.A.). Cows in Group P-34 were not sham-operated.

Blood sampling. A blood sample was collected via jugular venepuncture from all cows on the day before slaughter. In addition, cows in Group NP-34 were bled twice weekly from the time of surgery to slaughter. Plasma was obtained by centrifugation within $20 \mathrm{~min}$ of blood collection and stored at $-20^{\circ} \mathrm{C}$ until assayed for progesterone (Guilbault, Thatcher, Collier \& Wilcox, 1985).

Ovary collection. Cows were slaughtered on the morning of Day 17 or Day 34 after oestrus or after mating. Handling of ovaries and histological methods were as described previously (Dufour \& Roy, 1985). Briefly, both ovaries were collected within 20 min of exsanguination, fixed in BouinHollande's solution and embedded in paraffin wax. The CL-bearing ovary was serially sectioned at a thickness of $10 \mu \mathrm{m}$. Every fifth section was mounted, stained with haematoxylin and observed microscopically. Pregnancy in Groups P-17 and P-34 was confirmed by recovery of a conceptus with filamentous or expanded extraembryonic membranes, after dissection of the uterus. Cows that were mated but from which no conceptus was recovered $(\mathrm{N}=3$ ) were removed from the experiment.

Microscopic examination. All antral follicles $(>0.15 \mathrm{~mm})$ were counted and the diameters were estimated from the surface area of the section where the oocyte was found. Diameter of the largest follicles was estimated from the largest section limited by the basement membrane (Dufour \& Roy, 1985).

Antral follicles were classified as being atretic when 5 or more pycnotic bodies were counted amongst the granulosa cells of the section used to determine follicular diameter. Within atretic 
follicles, four levels of histological atresia were defined arbitrarily. Follicles containing 5-15, 16-25 and 26-50 pycnotic bodies, were designated stages 1, 2 and 3 of atresia respectively. Atretic follicles of stages 1,2 and 3 still presented mitotic figures, an intact basement membrane and the integrity of at least $50 \%$ of the layer of granulosa cells against the basement membrane. Atretic follicles with more than 50 pycnotic bodies and with both the granulosa cell layer and the basement membrane degenerated were at stage 4 of atresia. Atretic follicles of stages 1,2 and 3 were considered as being in early atresia whereas those of stage 4 represented follicles in late atresia.

Based on their diameter, non-atretic and atretic follicles were grouped into 6 classes as follows: class $1,0 \cdot 16-0.28 \mathrm{~mm}$; class $2,0.29-0.67 \mathrm{~mm}$; class $3,0.68-1.57 \mathrm{~mm}$; class $4,1.58-3.67 \mathrm{~mm}$; class 5 , $3.68-8.56 \mathrm{~mm}$ and class $6,>8.56 \mathrm{~mm}$. Within each class, the population of non-atretic follicles was expressed as a percentage of total number of non-atretic follicles in the ovary. The population of atretic follicles within each class was expressed as the percentage of the total number of atretic follicles in the ovary. Data reported are from CL-bearing ovaries.

Statistical analyses. Differences between groups in diameter of the two largest follicles, overall follicular population and follicular population within each size class were analysed by least-squares analysis of variance using the Statistical Analysis System (SAS, 1979). The mathematical model included sources of variation due to day of ovary collection, cow status and their interaction. Data expressed on a percentage basis (classes of non-atretic and atretic follicles) were transformed into their corresponding arc sinus values before statistical analyses. Differences in the stage of histological atresia between pregnant and non-pregnant cows were determined by $\chi^{2}$ analysis.

\section{Results}

\section{General}

There was no difference $(P>0 \cdot 1)$ between pregnant and non-pregnant cows in mean concentration of progesterone on the day before slaughter. Concentrations of progesterone on that day were elevated $(9 \cdot 6 \pm 1 \cdot 2$ (s.e.m.) $\mathrm{ng} / \mathrm{ml})$ in all cows but one in Group NP-17. Progesterone concentration in that cow was below $1 \mathrm{ng} / \mathrm{ml}$ and histological evidence of CL regression (smaller diameter) was observed. Statistical analyses of follicular data with or without this cow led to the same interpretation. Therefore, data from this cow were not excluded.

Hysterectomy induced CL maintenance in all cows in Group NP-34. This was confirmed in each case by (1) maintenance of high concentrations of progesterone $(>5 \mathrm{ng} / \mathrm{ml} ; 8.0 \pm 0.6 \mathrm{ng} / \mathrm{ml})$ between Days 4 and 34 after oestrus, (2) absence of oestrous behaviour throughout this period, (3) observation that the CL-bearing ovary at the time of surgery and at slaughter was on the same side and (4) histological evidence of an active CL.

\section{Largest $\left(F_{1}\right)$ and second largest $\left(F_{2}\right)$ follicles}

There was no difference $(P>0 \cdot 1)$ in mean diameter of non-atretic $\left(F_{1}\right.$ and $\left.F_{2}\right)$ and atretic $\left(F_{1}\right)$ largest follicles between pregnant and non-pregnant cows (Table 1). Mean diameter of $F_{2}$ atretic follicles tended to be smaller $(0.05<P<0.1)$ in pregnant cows.

\section{Overall population of antral follicles}

For each cow, population of non-atretic and atretic follicles is depicted (Fig. 1) as absolute number and as percentage of total number of follicles in ovary. The number of non-atretic and atretic follicles showed large variations between cows ranging from 26 to 368 and 4 to 23 follicles in non-pregnant cows and from 22 to 320 and 6 to 41 follicles in pregnant cows respectively. In 
Table 1. Mean diameter $(\mathrm{mm})$ of the largest $\left(\mathrm{F}_{1}\right)$ and second largest $\left(\mathrm{F}_{2}\right)$ nonatretic and atretic follicles in non-pregnant and pregnant cows on Days 17 or 34 after oestrus or after mating

\begin{tabular}{|c|c|c|c|c|c|}
\hline \multirow[b]{2}{*}{ Type of follicle } & \multicolumn{2}{|c|}{ Non-pregnant } & \multicolumn{2}{|c|}{ Pregnant } & \multirow[b]{2}{*}{ s.e.m.* } \\
\hline & Day 17 & Day 34 & Day 17 & Day 34 & \\
\hline \multicolumn{6}{|l|}{ Non-atretic } \\
\hline $\begin{array}{l}F_{1} \\
F_{2}\end{array}$ & $\begin{array}{l}4 \cdot 2 \\
2 \cdot 7\end{array}$ & $\begin{array}{l}3.9 \\
2.8\end{array}$ & $\begin{array}{l}5 \cdot 6 \\
3 \cdot 6\end{array}$ & $\begin{array}{l}4 \cdot 0 \\
3.0\end{array}$ & $\begin{array}{r} \pm 0.7 \\
\pm 0.3\end{array}$ \\
\hline \multicolumn{6}{|l|}{ Atretic } \\
\hline $\begin{array}{l}F_{1} \\
F_{2}\end{array}$ & $\begin{array}{l}6 \cdot 0 \\
3 \cdot 9^{\mathrm{a}}\end{array}$ & $\begin{array}{l}4 \cdot 4 \\
3 \cdot 6^{\mathrm{a}}\end{array}$ & $\begin{array}{l}5 \cdot 1 \\
3 \cdot 4^{b}\end{array}$ & $\begin{array}{l}4 \cdot 1 \\
2 \cdot 9^{b}\end{array}$ & $\begin{array}{l} \pm 0.7 \\
\pm 0.3\end{array}$ \\
\hline
\end{tabular}

* Standard error of mean. They are similar for each group.

Numbers sharing a different superscript differ from one another $(0.05<P<0 \cdot 1)$.

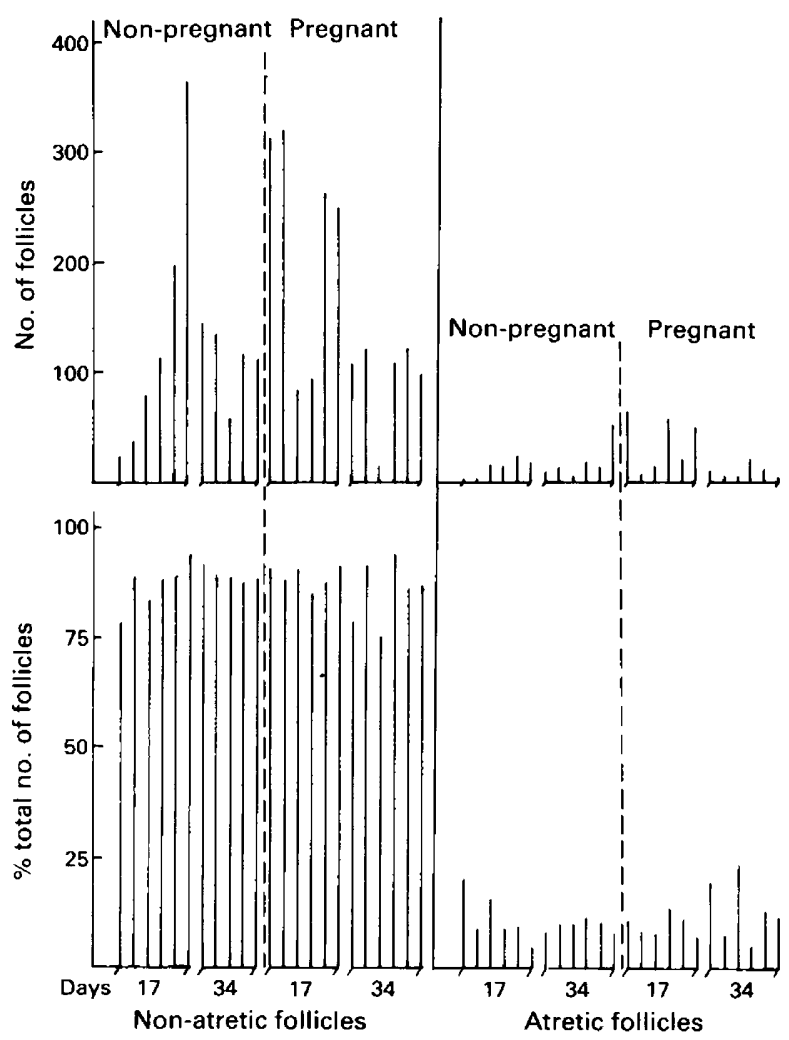

Fig. 1. Antral follicular population in the corpus luteum-bearing ovary of each cow on Day 17 or Day 34 after oestrus or after mating. The population of antral follicles (atretic and nonatretic) is expressed as (a) the number of follicles in the ovary and (b) the percentage of the total number of follicles in the ovary.

contrast, the population of non-atretic and atretic follicles expressed as a percentage of total number of follicles in the ovary was rather homogeneous between animals. Percentages of non-atretic and atretic follicles were $88.9 \pm 1.4$ and $11.1 \pm 1.5$ in non-pregnant cows and $88.1 \pm 1.4$ and $12.0 \pm 1.4$ in pregnant cows respectively. Overall, the population of non-atretic and atretic follicles expressed 
Table 2. Mean percentages* of (a) non-atretic and (b) atretic antral follicles, and (c) antral follicles within size classes atretic, and analysis of variance for various size classes of follicles in non-pregnant and pregnant cows on Days 17 and 34 after oestrus or after mating

\begin{tabular}{|c|c|c|c|c|c|c|c|c|c|}
\hline \multirow[b]{2}{*}{ Class } & \multirow[b]{2}{*}{ Size $(\mathrm{mm})$} & \multicolumn{2}{|c|}{ Non-pregnant } & \multicolumn{2}{|c|}{ Pregnant } & \multicolumn{3}{|c|}{ Level of significance } & \multirow{2}{*}{$\begin{array}{c}\text { Error } \\
\text { mean } \\
\text { square }\end{array}$} \\
\hline & & Day 17 & Day 34 & Day 17 & Day 34 & Day & Cow status & $\begin{array}{c}\text { Day } \times \\
\text { cow status }\end{array}$ & \\
\hline \multicolumn{10}{|c|}{ (a) Non-atretic follicles } \\
\hline 1 & $0 \cdot 16-0 \cdot 28$ & $39 \cdot 5$ & $36 \cdot 1$ & $25 \cdot 0$ & $27 \cdot 3$ & NS $\dagger$ & $P<0.002$ & NS & $65 \cdot 0$ \\
\hline 2 & $0.29-0.67$ & $41 \cdot 5$ & $46 \cdot 7$ & $51 \cdot 2$ & $46 \cdot 8$ & NS & $P<0.08$ & $P<0.09$ & $41 \cdot 2$ \\
\hline 3 & $0.68-1.57$ & 11.5 & $12 \cdot 4$ & $14 \cdot 7$ & $15 \cdot 8$ & NS & NS & NS & $41 \cdot 7$ \\
\hline 4 & $1.58-3.67$ & $6 \cdot 6$ & $4 \cdot 5$ & $8 \cdot 1$ & $9 \cdot 5$ & NS & $P<0.01$ & NS & $5 \cdot 7$ \\
\hline 5 & $3 \cdot 68-8 \cdot 56$ & $0 \cdot 8$ & $0 \cdot 2$ & 0.9 & 0.5 & NS & NS & NS & 0.8 \\
\hline $1+2$ & $0 \cdot 16-0 \cdot 67$ & $81 \cdot 1$ & $82 \cdot 8$ & $76 \cdot 2$ & $74 \cdot 1$ & NS & $P<0.03$ & NS & $48 \cdot 4$ \\
\hline $3+4$ & $0.68-3.67$ & $18 \cdot 1$ & $17 \cdot 0$ & $22 \cdot 9$ & $25 \cdot 4$ & NS & $P<0.03$ & NS & $46 \cdot 5$ \\
\hline $5+6$ & $>3.67$ & $0 \cdot 8$ & $0 \cdot 2$ & 0.9 & $0 \cdot 5$ & NS & NS & NS & $0 \cdot 8$ \\
\hline \multicolumn{10}{|c|}{ (b) Atretic follicles } \\
\hline 1 & $0 \cdot 16-0.28$ & $0 \cdot 0$ & $0 \cdot 0$ & 0.0 & 0.0 & - & - & - & - \\
\hline 2 & $0.29-0.67$ & $5 \cdot 8$ & $4 \cdot 0$ & $2 \cdot 9$ & $4 \cdot 6$ & NS & NS & NS & $41 \cdot 7$ \\
\hline 3 & $0.68-1.57$ & $19 \cdot 6$ & 14.9 & 21.5 & $37 \cdot 0$ & NS & $P<0.05$ & $P<0.07$ & $164 \cdot 8$ \\
\hline 4 & $1.58-3.67$ & $60 \cdot 8$ & $62 \cdot 4$ & 69.9 & $53 \cdot 9$ & NS & NS & NS & $488 \cdot 1$ \\
\hline 5 & $3 \cdot 68-8 \cdot 56$ & $12 \cdot 4$ & $18 \cdot 6$ & $5 \cdot 7$ & $4 \cdot 5$ & NS & $P<0.06$ & NS & $158 \cdot 4$ \\
\hline $1+2$ & $0 \cdot 16-0 \cdot 67$ & $5 \cdot 8$ & $4 \cdot 0$ & $2 \cdot 9$ & $4 \cdot 6$ & NS & NS & NS & $41 \cdot 7$ \\
\hline $3+4$ & $0.68-3.67$ & $80 \cdot 5$ & $77 \cdot 3$ & $91 \cdot 4$ & 90.9 & NS & $P<0.04$ & NS & $185 \cdot 9$ \\
\hline $5+6$ & $>3.67$ & $13 \cdot 7$ & $18 \cdot 7$ & $5 \cdot 7$ & $4 \cdot 5$ & NS & $P<0.05$ & NS & $163 \cdot 4$ \\
\hline \multicolumn{10}{|c|}{ (c) Atretic follicles within size classes } \\
\hline 1 & $0 \cdot 16-0 \cdot 28$ & - & - & - & - & - & - & - & - \\
\hline 2 & $0 \cdot 29-0.67$ & $2 \cdot 8$ & $1 \cdot 1$ & 0.8 & 1.7 & NS & NS & NS & $10 \cdot 6$ \\
\hline 3 & $0.68-1.57$ & $20 \cdot 1$ & $11 \cdot 4$ & $14 \cdot 3$ & $27 \cdot 0$ & NS & NS & $P<0.04$ & $92 \cdot 7$ \\
\hline 4 & $1.58-3.67$ & $53 \cdot 1$ & $58 \cdot 8$ & $48 \cdot 7$ & $45 \cdot 2$ & NS & NS & NS & $444 \cdot 5$ \\
\hline 5 & $3 \cdot 68-8 \cdot 56$ & $70 \cdot 8$ & $53 \cdot 3$ & $50 \cdot 0$ & $46 \cdot 4$ & NS & NS & NS & $2062 \cdot 2$ \\
\hline
\end{tabular}

*Expressed as percentage of total number of antral (a) non-atretic, (b) atretic follicles in the ovary and (c) as percentage of toal number of atretic and non-atretic follicles in each class.

$\dagger$ Not significant.

as a percentage of the total number of follicles in the ovary did not differ $(P>0 \cdot 1)$ between nonpregnant and pregnant cows. However, mean number of antral follicles (atretic + non-atretic) was lower $(P<0.06)$ in ovaries collected at Day 34 than in those collected on Day 17 (199 versus 120 follicles, s.e. \pm 28$)$. Although not significant $(P=0 \cdot 16)$, the decrease in mean number of antral follicles between Days 17 and 34 was more evident in pregnant (247 to 110) than nen-pregnant (150 to 128 ) cows.

\section{Follicular classes}

Non-atretic follicles. The population of non-atretic follicles within each class expressed as a percentage of the total number of non-atretic follicles in the ovary is given in Table 2(a). The percentage of non-atretic follicles within each class did not differ $(P>0 \cdot 1)$ in ovaries collected on Days 17 or 34 after oestrus or after mating. Non-atretic follicles in classes 1 and 2 accounted for $78 \%$ of all non-atretic follicles in the ovary. Classes 3 and 4 non-atretic follicles contained $21 \%$ of the total number of non-atretic follicles in the ovary whereas $<1 \%$ of the follicles were non-atretic follicles of classes 5 and 6.

On Days 17 and 34, the percentage of non-atretic follicles in class $1(P<0.002)$ or in pooled classes 1 and $2(P<0.03)$ was lower in pregnant than in non-pregnant cows. In contrast, the 
Table 3. Number and percentage (\%) of early and late atretic follicles (classes 3, 4 and 5) in non-pregnant and pregnant cows

\begin{tabular}{|c|c|c|c|c|c|c|}
\hline & \multicolumn{2}{|c|}{ Class 3} & \multicolumn{2}{|c|}{ Class 4} & \multicolumn{2}{|c|}{ Class 5} \\
\hline & $\begin{array}{c}\text { Non- } \\
\text { pregnant }\end{array}$ & Pregnant & $\begin{array}{c}\text { Non- } \\
\text { pregnant }\end{array}$ & Pregnant & $\begin{array}{c}\text { Non- } \\
\text { pregnant }\end{array}$ & Pregnant \\
\hline \multicolumn{7}{|l|}{ Atretic follicles } \\
\hline Early & 7 & 6 & 48 & 90 & 12 & 4 \\
\hline Late & 22 & 57 & 46 & 55 & 4 & 7 \\
\hline Total & 29 & 63 & 94 & 145 & 16 & 11 \\
\hline Total follicles* & 185 & 329 & 170 & 302 & 28 & 24 \\
\hline \multicolumn{7}{|l|}{$\%$ late atresia } \\
\hline $\begin{array}{l}\% \text { of total follicles } \\
\chi^{2}\end{array}$ & \multicolumn{2}{|c|}{$\mathrm{NS} \dagger$} & \multicolumn{2}{|c|}{ NS } & \multicolumn{2}{|c|}{ NS } \\
\hline$\%$ of atretic follicles & $75 \cdot 8$ & $90 \cdot 5$ & $48 \cdot 9$ & 37.9 & $25 \cdot 0$ & 63.6 \\
\hline$\chi^{2}$ & \multicolumn{2}{|c|}{$P<0.06$} & \multicolumn{2}{|c|}{ NS } & \multicolumn{2}{|c|}{$P<0.05$} \\
\hline
\end{tabular}

* Atretic + non-atretic follicles.

+ Not significant.

percentage of non-atretic follicles in class $4(P<0.01)$ or in pooled classes 3 and $4(P<0.03)$ was higher in pregnant than non-pregnant cows. The percentage of non-atretic follicles in class 2 tended to be higher in pregnant than non-pregnant cows but only on Day 17 after mating (day $\times$ status interaction; $P<0.09$ ).

Atretic follicles. Amongst all antral follicles (atretic and non-atretic), those that were atretic were primarily in classes 3 and $4(9.7 \%)$ and to a lesser extent in classes 2 and $5(1.8 \%)$. None of the follicles in class 1 and very few follicles $(<0.5 \%)$ in class 6 were classified as being in a state of histological atresia.

The percentage of atretic follicles in various size classes was expressed as percentage of total number of atretic follicles and is given in Table 2(b). The percentage of atretic follicles in class 2 did not differ $(P>0 \cdot 1)$ on either day between pregnant and non-pregnant cows. However, pregnancy affected the distribution of atretic follicles in larger classes. The percentage of atretic follicles in class 3 was higher $(P<0.05)$ in pregnant than non-pregnant cows but this difference was more evident on Day 34 of pregnancy (day $\times$ status interaction, $P<0.07$ ). Likewise, the percentage of atretic follicles in pooled classes 3 and 4 was higher $(P<0.04)$ in pregnant than in non-pregnant cows $(91 \cdot 1$ vs $78 \cdot 9$, respectively). In contrast, the percentage of atretic follicles in class $5(P<0.06)$ or in pooled classes 5 and $6(P<0.05)$ was lower in pregnant than in non-pregnant cows.

Amongst the total number of follicles (atretic + non-atretic) in a class, the percentage of those that were atretic increased as follicular size increased (Table 2(c)). Within class 3, pregnant cows had a lower percentage of atretic follicles than did non-pregnant cows on Day 17 but not on Day 34 (day $\times$ status interaction, $P<0 \cdot 04$ ).

\section{Level of atresia}

The numbers and percentages of early and late atretic follicles for pregnant and non-pregnant cows are given in Table 3. Relative to the total number of follicles in the class, the percentage of late atretic follicles in classes 3,4 or 5 did not differ between pregnant and non-pregnant cows $(P>0 \cdot 1)$. However, amongst all atretic follicles in a class, the percentage of those that were in a state of late atresia in classes $3(P<0.06)$ and $5(P<0.05)$ was higher in pregnant than in nonpregnant cows. 


\section{Discussion}

The high variability in the population of antral follicles amongst cows was in the range of that reported previously (Erickson, 1966; Monniaux, Chupin \& Saumande, 1983; Monniaux, Mariana \& Gibson, 1984; Dufour \& Roy, 1985). There were about 8-9 times more non-atretic than atretic follicles in the ovary of each animal and the number of these two types of follicles was positively correlated $(r=0.78)$. This supports an earlier claim (D. Monniaux, J. C. Mariana, W. R. Gibson \& C. Roux, unpublished) that an equilibrium prevails between the distribution of atretic and nonatretic follicles, despite large variation in absolute number amongst cows.

Comparisons of follicular populations between pregnant and non-pregnant cows were made during a functional luteal phase at a time when progesterone concentrations remained elevated ( $>5 \mathrm{ng} / \mathrm{ml}$ ) for comparable periods of time. This was achieved by collecting ovaries in non-pregnant cows before the onset of luteolysis (except in one cow), or after CL maintenance was induced by hysterectomy as reported previously (Wiltbank \& Casida, 1956; Malven \& Hansel, 1964; Ginther, 1981). Histological examinations were made on CL-bearing ovaries based upon previous reports indicating that, early in pregnancy, processes involved in luteal maintenance (Ginther, 1981) as well as changes in uterine and ovarian blood flow (Ford \& Chenault, 1981) or in number of visible ovarian follicles (Rexroad \& Casida, 1975) were localized to the uterine horn ipsilateral to the conceptus or in the CL-bearing ovary.

In the present study, pregnancy altered the distribution of follicles in the CL-bearing ovaries primarily at two levels. Firstly, the proportion of small non-atretic follicles (class 1) was lowered by pregnancy while that of non-atretic follicles in larger classes at Day 17 (class 2) and later at Day 34 (classes 3 and 4) of gestation was increased. Secondly, pregnancy was associated with an increased level of atresia in larger classes of follicles. Factors such as gonadotrophin concentration (Dufour, Cahill \& Mauleon, 1979; Monniaux et al., 1983, 1984), season (Dufour \& Guilbault, 1984), level of nutrition (Maurasse, Matton \& Dufour, 1985), breed (Driancourt, Cahill \& Bindon, 1985) and post-partum interval (Dufour \& Roy, 1985) also altered the close equilibrium amongst follicular size classes in ewes and cows. The results of the present study therefore suggest that pregnancy induces a more rapid turnover of follicles from class 1 to classes 3 and 4 but may limit further follicular growth by increasing the degree of atresia in larger size classes.

However, depletion of the pool of small non-atretic follicles was a characteristic of follicular activity during early pregnancy (present study) and the post-partum interval (Dufour \& Roy, 1985) in the cow. This suggests that, under various physiological conditions (e.g. gestation, post partum), the pool of small antral follicles may be critical in the regulation of replenishment of follicles from the preantral pool and the ensuing depletion to larger antral follicles.

Rexroad \& Casida (1975) suggested that the CL of gestation acted on follicles to increase atresia and alter their growth rates during gestation in the cow. However, two lines of evidence would suggest that some of the alterations of follicular growth and/or atresia during early gestation are induced by the conceptus. Firstly, distribution of follicles in various size classes was similar before the onset of luteolysis and after induction of CL maintenance by hysterectomy in non-pregnant cows. Secondly, examination of terminal follicular growth by echography revealed a diminution in the number of large follicles ( $>5 \mathrm{~mm}$ ) specifically on the CL-bearing ovary between 24 and 34 days of gestation in the cow but not after induction of CL maintenance by hysterectomy (see Thatcher, Bazer, Sharp \& Roberts, 1986). In the present study, the effect of the conceptus on early follicular development was observed as early as Day 17 of pregnancy.

Factors originating from the conceptus (Northey \& French, 1980; Heyman, Camous, Fevre, Meziou \& Martal, 1984; Plante, Bousquet, Guay \& Goff, 1984) appear to reduce endometrial secretion of PGF-2 $\alpha$ (Knickerbocker, Thatcher, Bazer, Barron \& Roberts, 1984; Thatcher et al., 1984) and contribute to CL maintenance during early pregnancy in the cow. However, although PGF- $2 \alpha$ from the uterus appears to be the ultimate effector component of luteolysis in the cow (Nancarrow et al., 1973; Shemesh \& Hansel, 1975; Thatcher et al., 1984, 1985), recent evidence indicates that 
ovarian follicles also are involved (Chupin \& Saumande, 1981; Villa-Godoy et al., 1985; Fogwell et al., 1985). Increases in concentrations of oestradiol-17 (originating from large follicles) in the uteroovarian vein adjacent to the CL-bearing ovary preceded the increase in PGF-2 $\alpha$ before spontaneous luteolysis in the cow (Fogwell et al., 1985). Thus by increasing the turnover of small non-atretic follicles and by increasing the level of atresia of follicles in the larger size classes, the bovine conceptus may decrease the ability of ovarian follicles to release factors that directly (intra-ovarian) or indirectly (uterine PGF-2 $\alpha$ ) induce CL regression during early pregnancy (until Day 34 ).

Mechanisms implicated in such alterations of follicular development in the CL-bearing ovary of cattle during early pregnancy still remain speculative. It has been suggested that FSH (Findlay \& Cumming, 1977; Baird, 1983; Cahill, Driancourt, Chamley \& Findlay, 1985) as well as intra- or inter-ovarian regulatory agents (Cahill et al., 1985) may control growth rates of small antral follicles $(<2 \mathrm{~mm})$. Furthermore, proteins secreted by large antral follicles are likely candidates for the control of selection of ovulating follicles through atresia in ewes (Driancourt et al., 1985; Cahill et al., 1985) and pigs (Ledwitz-Rigby, 1985). The bovine conceptus may alter follicular function by an effect on such regulatory agents. Alternatively, possible effects of localized changes in uterine or ovarian blood flows during early pregnancy in cattle (Ford \& Chenault, 1981) as well as systemic effects on both ovaries cannot be ruled out. Indeed, follicular alteration of the CL-bearing ovary may have induced local changes in intra-ovarian regulators (e.g. inhibin) which then may have influenced pituitary function.

Despite inducing more atresia of large antral follicles, the presence of a conceptus did not affect the diameter of the largest follicle $\left(F_{1}\right)$ at a time when the turnover rate of $F_{1}$ and $F_{2}$ follicles is highest in cyclic cows (Matton, Adelakoun, Couture \& Dufour, 1981). However, that does not rule out the possibility that the function of the $F_{1}$ follicle has been altered by the conceptus as biochemical changes in follicular fluids may precede morphological signs of atresia in cattle (Ireland \& Roche, 1983). Furthermore, the lower percentage of class 5 atretic follicles in pregnant cows may be due to the fact that higher proportions of these large follicles were in late atresia or perhaps already degenerate at the time of ovary collection. This is in keeping with the observation that the number of large follicles ( $>5 \mathrm{~mm}$ ) on the CL-bearing ovary decreased during early (as seen by echography: Thatcher et al., 1986 or mid-pregnancy (Rexroad \& Casida, 1975) in cattle.

In summary, the presence of a conceptus appears to favour a more rapid turnover of follicles from small to large size classes but limits further growth by increasing atresia. Conceptus-induced changes in follicular function may be critical to luteal maintenance at the time of maternal recognition of pregnancy in cattle. Conversely, endocrine changes associated with such alteration may be more permissive to development of a viable conceptus.

We thank Mr A. Bouchard for technical assistance in histology; Mr A. Belleau for performing the statistical analyses; and Mrs L. Côté for typing this manuscript. Agriculture Canada Research Station, Lennoxville, Contribution No. 173.

\section{References}

Baird, D.T. (1983) Factors regulating the growth of the preovulatory follicle in the sheep and human. $J$. Reprod. Fert. 69, 343-352.

Brunner, M.A., Donaldson, L.E. \& Hansel, W. (1969) Exogenous hormones and luteal function in hysterectomized and intact heifers. J. Dairy Sci.52, 1849-1854.

Cahill, L.P., Driancourt, M.A., Chamley, W.A. \& Findlay, J.K. (1985) Role of intrafollicular regulators and FSH in growth and development of large antral follicles in sheep. J. Reprod. Fert. 75, 599-607.
Chupin, D. \& Saumande, J. (1981) Effect of exogenous prostaglandin and/or estrogen on luteolysis after electrocauterization of the largest follicles at the end of the bovine estrous cycle. Theriogenology 16, 497-504.

Driancourt, M.A., Cahill, L.P. \& Bindon, B.M. (1985) Ovarian follicular populations and preovulatory enlargement in Booroola and control Merino ewes. $J$. Reprod. Fert. 73, 93-107.

Dufour, J.J. \& Guilbault, L.A. (1984) Ovarian follicular 
population changes with the advance of the breeding season in intact and unilaterally ovariectomized ewes. J. Reprod. Fert. 70, 363-368.

Dufour, J.J. \& Roy, G.L. (1985) Distribution of ovarian follicular populations in the dairy cow within 35 days after parturition. J. Reprod. Fert. 73, 229-235.

Dufour, J., Cahill, L.P. \& Mauleon, P. (1979) Short- and long-term effects of hypophysectomy and unilateral ovariectomy in ovarian follicular populations in sheep. J. Reprod. Fert. 57, 301-309.

Eley, R.M., Thatcher, W.W. \& Bazer, F.W. (1979) Luteolytic effect of oestrone sulphate on cyclic beef heifers. J. Reprod. Fert. 55, 191-193.

Erickson, B.H. (1966) Development and senescence of the postnatal bovine ovary. J. Anim. Sci. 25, 800-805.

Findlay, J.K. \& Cumming, I.A. (1977) The effect of unilateral ovariectomy on plasma gonadotropin levels, estrus and ovulation rate in sheep. Biol. Reprod. 17, $178-183$.

Ford, S.P. \& Chenault, J.R. (1981) Blood flow to the corpus luteum-bearing ovary and ipsilateral uterine horn of cows during the oestrous cycle and early pregnancy. J. Reprod. Fert. 62, 555-562.

Fogwell, R.L., Cowley, J.L., Wortman, J.A., Ames, N.K. \& Ireland, J.J. (1985) Luteal function in cows following destruction of ovarian follicles at midcycle. Theriogenology 23, 389-398.

Ginther, O.J. (1981) Local versus systemic uteroovarian relationships in farm animals. Acta vet. scand., Suppl. 77, $103-115$.

Guilbault, L.A., Thatcher, W.W., Collier, R.J. \& Wilcox, C.J. (1985) Periparturient endocrine changes of conceptus and maternal units in Holstein heifers bearing genetically different conceptuses. J. Anim. Sci. 61, 1505-1515.

Heyman, Y., Camous, S., Fevre, J., Meziou, W. \& Martal, J. (1984) Maintenance of the corpus luteum after uterine transfer of trophoblastic vesicles to cyclic cows and ewes. J. Reprod. Fert. 70, 533-540.

Hixon, J.E., Pimental, C.A., Weston, P.G., Chafetz, E.P., Shanks, R.D. \& Hansel, W. (1983) A luteolytic interaction between estradiol benzoate and prostaglandin $\mathrm{F}_{2 \alpha}$ in cattle. J. Anim. Sci. 56, 1190-1197.

Ireland, J.J. \& Roche, J.F. (1983) Development of nonovulatory antral follicles in heifers: changes in steroids in follicular fluid and receptors for gonadotropins. Endocrinology 112, 150-156.

Knickerbocker, J.J., Thatcher, W.W., Bazer, F.W., Barron, D.H. \& Roberts, R.M. (1984) Inhibition of estradiol-17ß (E) induced uterine prostaglandin $F_{2 \alpha}$ $\left(\mathrm{PGF}_{2 a}\right)$ production by bovine conceptus secretory proteins (CSP). J. Anim. Sci. 59 (Suppl. 1), 368, Abstr.

Ledwitz-Rigby, F. (1985) Androgens enhance follicular regulatory protein (FRP) stimulation of progesterone secretion by porcine granulosa cells. Biol. Reprod. 32 (Suppl. 1), 137, Abstr.

Malven, P.V. \& Hansel, W. (1964) Ovarian function in dairy heifers following hysterectomy. J. Dairy Sci.47, 1388-1393.

Matton, P., Adelakoun, V., Couture, Y. \& Dufour, J.J. (1981) Growth and replacement of the bovine ovarian follicles during the estrous cycle. J. Anim. Sci. 52, $813-820$.
Maurasse, C., Matton, P. \& Dufour, J.J. (1985) Ovarian follicular populations at two stages of an estrous cycle in heifers given high energy diets. J. Anim. Sci. 61, $1194-1210$.

Miller, K.F., Critser, J.K., Rowe, R.F. \& Ginther, O.J. (1979) Ovarian effects of bovine follicular fluid treatment in sheep and cattle. Biol. Reprod. 21, 537-544.

Monniaux, D., Chupin, D. \& Saumande, J. (1983) Superovulatory responses of cattle. Theriogenology 19, 55-81.

Monniaux, D., Mariana, J.C. \& Gibson, W.R. (1984) Action of PMSG on follicular populations in the heifer. J. Reprod. Fert. 70, 243-253.

Nancarrow, C.B., Buckmaster, J., Chamley, W.A., Cox, R.I., Cumming, I.A., Cummins, L., Drinin, J.P., Findlay, J.K., Goding, J.R., Restall, B.J., Schneider, W. \& Thorburn, G.D. (1973) Hormone changes around oestrus in the cow. J. Reprod. Fert. 32, $320-321$.

Northey, D.L. \& French, L.R. (1980) Effect of embryo removal and intrauterine infusion of embryonic homogenates on the lifespan of the bovine corpus luteum. J. Anim. Sci. 50, 298-302.

Plante, C., Bousquet, D., Guay, P. \& Goff, A.K. (1984) Embryonic tissue associated with the embryonic signal in early pregnancy. Theriogenology 21, 253, Abstr.

Rexroad, C.E., Jr \& Casida, L.E. (1975) Ovarian follicular development in cows, sows and ewes in different stages of pregnancy as affected by number of corpora lutea in the same ovary. J. Anim. Sci. 41, 1090-1097.

SAS (1979) SAS User's Guide. Statistical Analysis System Institute, Inc., Cary, NC.

Shemesh, M. \& Hansel, W. (1975) Levels of prostaglandin $F$ (PGF) in the bovine endometrium, uterine venous, ovarian artery and jugular plasma during the estrous cycle. Proc. Soc. exp. Biol. Med. 148, 123-126.

Thatcher, W.W., Wolfenson, D., Curl, J.S., Rico, L.E., Knickerbocker, J.J., Bazer, F.W. \& Drost, M. (1984) Prostaglandin dynamics associated with development of the bovine conceptus. Anim. Reprod. Sci. 7, 149-176.

Thatcher, W.W., Knickerbocker, J.J., Bartol, F.F., Bazer, F.W., Roberts, R.M. \& Drost, M. (1985) Maternal recognition of pregnancy in relation to the survival of transferred embryos: endocrine aspects. Theriogenology 23, 129-143.

Thatcher, W.W., Bazer, F.W., Sharp, D.C. \& Roberts, R.M. (1986) Interrelationships between uterus and conceptus to maintain corpus luteum function in early pregnancy: sheep, cattle, pigs and horses. $J$. Anim. Sci. 62 (Suppl. 2) 25-46.

Villa-Godoy, A., Ireland, J.J., Wortman, J.A., Ames, N.K., Hughes, T.L. \& Fogwell, R.L. (1985) Effect of ovarian follicles on luteal regression in heifers. $J$. Anim. Sci. 60, 519-527.

Wiltbank, J.N. \& Casida, L.E. (1956) Alteration of ovarian activity by hysterectomy. J. Anim. Sci. 15, 134-140.

Wiltbank, J.N., Ingalls, J.E. \& Rowden, W.W. (1961) Effects of various forms and levels of estrogen alone or in combinations with gonadotropins on the estrous cycle of beef heifers. J. Anim. Sci. 20, 341-346.

Received 9 December 1985 